\title{
$x \mathrm{Li}_{2} \mathrm{O}-(1-x) \mathrm{SiO}_{2}$ 結晶に適用する原子間相互作用の考察
}

\author{
山本 優也 ${ }^{* 1}$, 澤口直哉 ${ }^{1,2}$, 佐々木 眞 ${ }^{1,2}$
}
1 室蘭工業大学大学院 工学研究科, $\bar{\top} 050-8585$ 北海道室蘭市水元町 27 番 1 号
2 室蘭工業大学環境調和材料工学研究センター, $\bar{\top} 050-8585$ 北海道室蘭市水元町 27 番 1 号
*e-mail:14042074@mmm.muroran-it.ac.jp

(Received: July 25, 2014; Accepted for publication: August 21, 2014; Online publication: September 30, 2014)

Ionic charges of lithium silicates for molecular dynamics simulations were calculated by using density functional theory calculations. The reproducibility of simulated crystal structures were improved compared to that of previous works. The results suggest that the alkali ionic charge should be according to the $A_{2} \mathrm{O} / \mathrm{SiO}_{2}$ ratio because of difference of the bond nature.

キーワード: Molecular dynamics, Density functional theory, Lithium silicates, Interatomic potential models, CASTEP

\section{1 目的}

我々は分子動力学法(Molecular dynamics, MD)を用いて アルカリケイ酸塩結晶 $\left(x A_{2} \mathrm{O}-(1-x) \mathrm{SiO}_{2}, A=\right.$ Alkalies $)$ 中 のイオンの動的挙動を研究している. MD 法に用いる原 子間相互作用モデルのCoulomb 相互作用は化学結合を特 徵づける. 我々は第一イオン化エネルギーが低いアルカ リ元素には形式電荷を, Si やO には結晶構造の再現性 を向上させるため, $x$ に応じて変化する電荷を経験的に 設定してきた(経験的電荷). しかし，いずれの元素につ いても，どのような電荷設定が最適なのか分かっていな い. 本研究では電荷設定の理論的根拠を探るために, 密 度汎関数理論 (Density functional thory, DFT) 計算を用いた 考察を行った.

\section{2 方法}

対象とした結晶[1-6]を Table 1 に示した. バンド計算 ソフトウェアはCASTEP [7] を用いた. ノルム保存型擬 ポテンシャル [8] を用い, 交換相関汎関数にはGGA-PBE [9] を使用した.K点メッシュはソフトウェア側で自動 的に処理した值を用いた。平面波カットオフエネルギー は全ての結晶で $1500 \mathrm{eV}, \mathrm{SCF}$ tolerance は $1.0 \times 10^{-6} \mathrm{eV} /$ atom の条件で構造最適化を行った. Mulliken Population Analysis [10] で各サイトのイオンの電荷を求めた. MD 計算にはMXDORTO [11]を用いた. 約 1000 1200 原子か らなる結晶モデルに温度 $300 \mathrm{~K}$, 圧力 $0.1 \mathrm{MPa}$ のPT ア ンサンブルを適用した。刻み時間は $2.0 \mathrm{fs}$ とし, 1000 ス テップの緩和計算後の 5000 ステップの計算を解析した. 原子間相互作用モデル [12] には，電荷の影響を検討しや すいCoulomb 力項と近接反発力項のみからなる式(1)の モデルを, 全ての原子対へ適用した. DFT 計算で得ら

Table 1. Calculated crystals

\begin{tabular}{|c|c|c|c|c|c|}
\hline \multirow{2}{*}{$\begin{array}{c}\text { Composition, } x \\
x \mathrm{Li}_{2} \mathrm{O}-(1-x) \mathrm{SiO}_{2}\end{array}$} & \multirow{2}{*}{ Space group (Num.) } & \multicolumn{3}{|c|}{ Lattice parameter/nm } & \multirow{2}{*}{$\begin{array}{l}\text { Number of } \\
\text { ions in cell }\end{array}$} \\
\hline & & $a$ & $b$ & $c$ & \\
\hline $0.00[1]$ & P3 (221) & 0.4929 & 0.4929 & 0.5319 & 9 \\
\hline 0.33 [2] & $\operatorname{Ccc} 2(37)$ & 0.5807 & 1.4582 & 0.4773 & 36 \\
\hline $0.50[3]$ & Cmc21 (36) & 0.9392 & 0.5397 & 0.4660 & 24 \\
\hline $0.60[4]$ & P421 m (113) & 0.7715 & 0.7715 & 0.4880 & 30 \\
\hline $0.80[5]$ & P63 cm (185) & 0.5424 & 0.5424 & 1.0626 & 30 \\
\hline $1.00[6]$ & Fm3 m (225) & 0.4807 & 0.4807 & 0.4807 & 9 \\
\hline
\end{tabular}




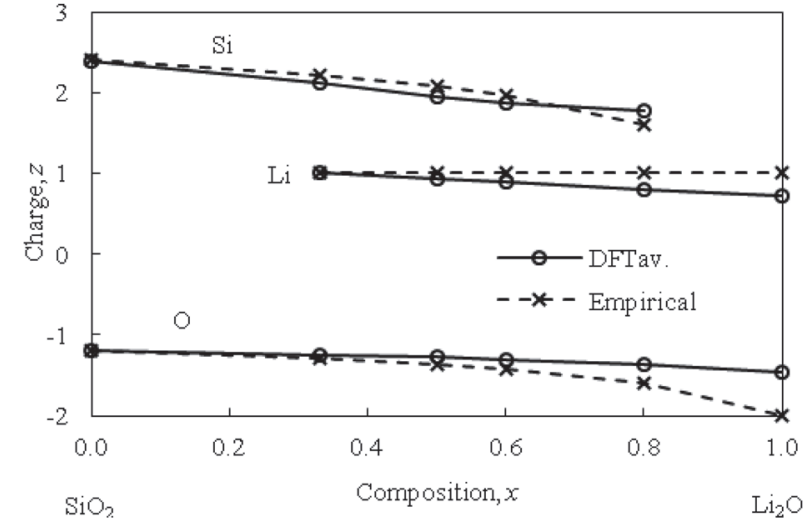

Figure 1. "DFTav." and empirical charge of ions in $x \mathrm{Li}_{2} \mathrm{O}-(1-x)$ $\mathrm{SiO}_{2}$ applied to the molecular dynamics simulations.

れる電荷は同じ元素でもサイト毎に值が異なる. 一方, 我々は古典的MD シミュレーションに対し, 同一元素の イオンには同じ電荷を付与してきた.これに合わせるた めに, 電荷は元素毎にDFT 計算で求めた電荷の平均值 を用いることにした(DFTav. 電荷)。式(1)の近接反発力 項の $a, b$ パラメータは文献值 [2-5] の格子定数, 密度を 再現するように結晶毎に最適化した。 得られたOの $a$ パ ラメータは $x$ に対し系統的に変化した。

$$
U_{i j}\left(r_{i j}\right)=\frac{z_{i} z_{j} e^{2}}{4 \pi \varepsilon_{0} r_{i j}}+f_{0}\left(b_{i}+b_{j}\right) \exp \left[\frac{a_{i}+a_{j}-r_{i j}}{b_{i}+b_{j}}\right]
$$

\section{3 結果・考察}

Figure 1 にMD 計算に用いた各イオンの電荷を示す. 破線で示したように Li の経験的電荷は, 形式電荷で一 定であるが, "DFTav. 電荷”では $x$ の増加に伴い減少し た. O の経験的電荷の絶対值は, 高アルカリ組成になる に従い, "DFTav. 電荷”よりも大きいことが分かった. Si の電荷は両手法による差異は見られなかった。 O-O 間の 二体相関関数, $\mathrm{PCF}(\mathrm{O}-\mathrm{O})$ (Pair correlation function, $\mathrm{PCF})$ よ り，これらの電荷の差が構造に与える影響を調べた. $x$ $\leqq 0.60$ の結晶については, 経験的電荷と”DFTav. 電荷” による MD 計算の PCF (O-O) はほぼ一致した.しかし, Figure 2 に示す $x=0.80$ の PCF $(\mathrm{O}-\mathrm{O})$ において, ”DFTav. 電荷”を用いた場合は経験的電荷に比べ, $\mathrm{PCF}(\mathrm{O}-\mathrm{O})$ の第 一ピークが短距離側ヘシフトした。これは経験的電荷の 場合, Liが形式電荷であるため, 電気的中性条件により 高アルカリ組成ではOの電荷の絶対值が大きくなってし まい, O-O 間の反発が過大評価されているからだと考え

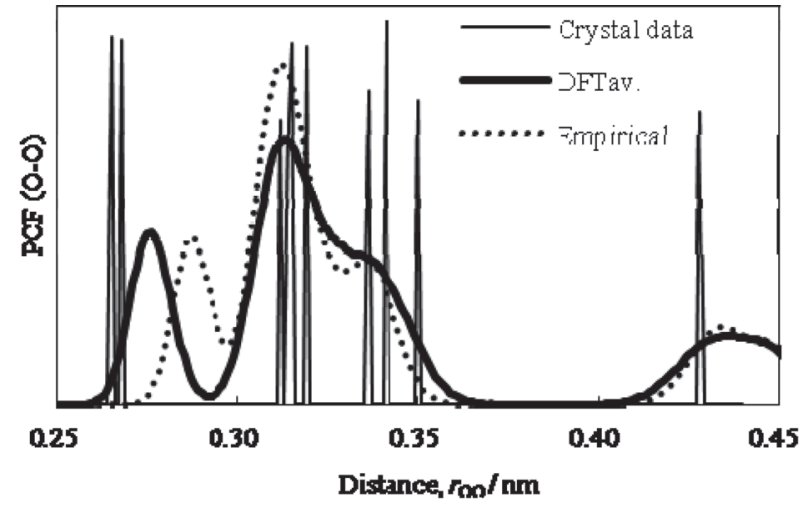

Figure 2. $\mathrm{PCF}(\mathrm{O}-\mathrm{O})$ of $x=0.80$ crystal for DFTav. and empirical charge.

られる. また, "DFTav. 電荷”の適用により, PCF(O-O) の第一ピーク位置は結晶学データが示す O-O 距離に近づ いた. したがって, ”DFTav. 電荷”の適用により結晶構造 の再現性が改善されたと考えられる。

\section{4 結論}

DFT 計算から得た電荷を MD 法へ適用した 結果, リ チウムケイ酸塩結晶の結晶構造の再現性を向上させるこ とができた. また, "DFTav. 電荷”は電荷設定の指標とな る可能性がある. 今後は他の結晶への沉用性を調べ, 定 式化等を検討する予定である.

\section{参考文献}

[1] V. Gibbs, et al., Mater. Res. Soc. Sym. Proc. 121, 155 (1988). [CrossRef]

[2] de. Jong, et al., J. Acta Crystallogr. B, 54, 568 (1998). [CrossRef]

[3] K. Hesse, Acta Crystallogr. B, 33, 901 (1977). [CrossRef]

[4] H. Völlenkle, et al., Monatsh. Chem. 100, 295 (1969). [CrossRef]

[5] R. Hofmann, R. Hoppe, Z. Anorg. Allg. Chem. 555, 118 (1987). [CrossRef]

[6] E. Zintl, et al., Zeit. Elektrochemie, 83, 32 (1983).

[7] J. Clark, et al., Z. Kristallogr. 220, 567 (2005). [CrossRef]

[8] R. Hamann, et al., Phys. Rev. Lett. 43, 1494 (1979). [CrossRef]

[9] J. P. Perdew, K. Burke, M. Ernzerhof, Phys. Rev. Lett. 77, 3865 (1996). [Medline] [CrossRef]

[10] R. Mulliken, J. Chem. Phys. 23, 1833 (1955). [CrossRef]

[11] K. Kawamura, MXDORTO, JCPE, \#29, (1992).

[12] K. Kawamura,"Pasokonbunshisimyure-shon Bunshidourikigakunyuumon", Kaibundou, (1990). 